\title{
Exodus of clergy: A practical theological grounded theory exploration of Hatfield Training Centre trained pastors
}

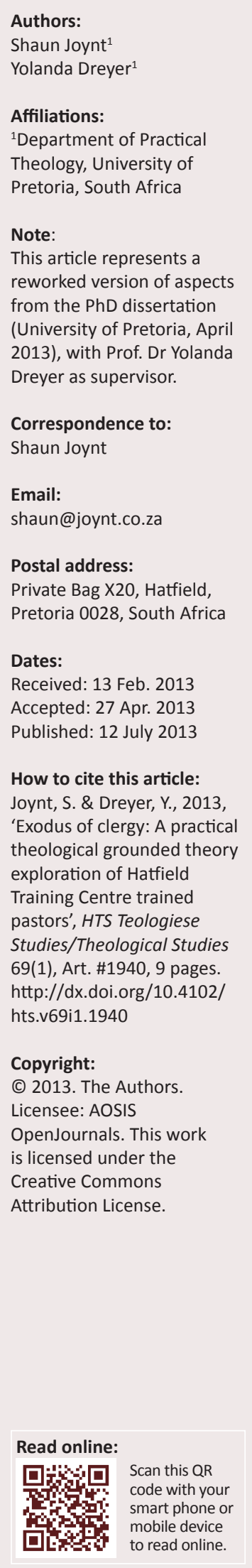

There is a shortage of clergy, at least in the Roman Catholic Church. Protestant churches in general are experiencing more of a distribution or placement challenge than a shortage. The two greatest hindrances to addressing the Protestant clergy distribution challenge are a lack of adequate compensation for clergy and the undesirable geographical location of a number of churches, as perceived by clergy. Influences such as secularisation, duality of vocation, time management, change in type of ministry, family issues, congregational and denominational conflict, burnout, sexual misconduct, divorce or marital problems, and suicide, affect clergy. Studies on the shortage of clergy have been conducted mostly in the USA and Europe and not in South Africa. This article focuses on the research gap by means of a practical theological grounded theory exploration of the exodus of clergy. Grounded theory methodology is used to identify the reasons why clergy trained at a Bible college of a Protestant charismatic mega church leave full-time pastoral ministry. Findings correspond to previous studies with two reasons appearing more frequently than others: responding to a call and leadership related issues. Firstly, respondents differed in their replies with respect to reconciling their exit from full-time pastoral ministry with their call. The replies included not being called, a dual call, or called but left anyway. Secondly, respondents indicated that leadership influence was mostly negative with regard to affirming their call.

\section{Research gap and interest}

The journey of enquiring if there is a shortage of clergy started with my personal experience of pastoral ministry in a small town which led to close friendships with fellow clergy of other denominations, namely Methodist and Anglican clergy. Various challenges were communicated to one another, including 'struggles' experienced with the senior leadership of the respective congregations. My peers felt as if they were not being understood or 'heard'. This continued for some time and, subsequent to our departure from that town, I learnt that the Methodist youth minister had left and the Anglican youth minister was still struggling with what may be termed 'leadership style conflict' (cf. Fernandez 2001:x, 1). During the years that have transpired since leaving the ministry in that small town, I have continually asked the question, 'why were so many of my contemporaries discontent in ministry?' And, 'why have a number of them left their congregations, and the church for that matter?' What are the reasons for this supposed 'exodus of clergy' and are there intervention methods that could be developed to stem unnecessary departures? A huge 'investment' is made in training clergy in terms of determining their call, theological education, and apprenticeship. So, what are the factors that contribute to that decision to leave full-time or salaried ministry?

The church as an organisation requires clergy who are trained to serve its mission. When a shortage of clergy occurs, the mission is compromised. So, identifying factors that contribute to a clergy shortage would serve both the church as an organisation and her members well. An extensive search of leading electronic journal databases, including Cambridge, EBSCoHost, Emerald, Google Scholar, Ingenta Connect, JSTOR, Proquest, SA ePublications, Sage, and SpringerLink, suggests no academic research has been conducted regarding a shortage of clergy within South Africa.

European and USA studies regarding a shortage of clergy indicate a shortage in the Roman Catholic Church (cf. Tentler 1998:348; Carroll 2001:1; Fernandez 2001:ix-x) whilst Protestant churches in general are experiencing more of a distribution or placement challenge than a shortage (cf. Chaves 2001:36; Jud, Mills \& Burch 1970:59). The two greatest hindrances to addressing this clergy distribution or placement challenge amongst Protestant churches are a lack of adequate compensation for clergy and the undesirable location (geographical), as perceived by clergy, of the church (Chaves 2001:36; Jud et al. 1970:59). This study seeks to address the research gap within the South African context by means of a practical theological grounded theory exploration of the exodus of clergy. 
Various factors have contributed to the shortage of clergy. These factors include the secularisation and duality of vocation, marital and family challenges, conflict and financial issues, and a multitude of others (Hoge \& Wenger 2005:49; cf. Carroll 2006:167-169; Percy 2006:26-29). Additional factors include time management, change in type of ministry, burnout, sexual misconduct, and suicide. A change in the roles and responsibilities of clergy also contribute to clergy role confusion (Gustafson 1965:171-202; cf. Trull \& Carter 2004:22; Cahill 2012:92-115). Clergy are not only unsure as to what to do but also whom to serve: individuals, the congregation, or God (Trull \& Carter 2004:22).

Against this background, the main purpose of this study is to determine the reasons why clergy leave full-time pastoral ministry within a South African context. The objectives are to determine what factors influence or cause clergy to abandon full-time pastoral ministry, in other words, 'why do they leave?' Qualitative research, including conducting interviews with criteria-qualifying respondents and applying grounded theory methodology, is used to identify the reasons why clergy trained at a Bible college of a Protestant charismatic mega church leave full-time pastoral ministry.

The rest of this article is presented in four parts. Firstly, it reviews the extant literature relevant to a shortage of clergy. Then the research methodology is presented and data analysis techniques are discussed. Next, the findings are discussed and summarised. The article concludes with a discussion of the study's implications and directions for future research.

\section{Why clergy leave}

Clergy leave the employment of the church as an organisation for various reasons. These include personal reasons (marriage, divorce, a partner has a new job, moving closer to children, health, and retirement), a new calling (a different ministry or vocation), feeling unappreciated, conflict (intercongregational and staff), being mismatched (wrong pastor or congregation), and time to leave (the work has been done) (Stephens 2003:1-4; Hoge \& Wenger 2005:35-45). Additional reasons include frustration with ecclesiastical structures and Episcopal policies, size and concentration of the diocese, and conflict with leadership (Seidler 1979:763, 765). Factors such as secularisation, duality of vocation, time management, change in type of ministry, family issues, congregational and denominational conflict, burnout, sexual misconduct, divorce or marital problems, and suicide, affect clergy's decision to leave the full-time pastoral ministry of the church. Each of these will be elaborated on in the following paragraphs.

Research in the 1960s, dominated by secularisation theory, changed the role and identity of the Protestant minister, particularly in the aspect of professionalism (Hoge \& Wenger 2005:4; Mills 1985:167-186). Professionalism steered the 'focus of the clergy's work from fulfilling a traditional calling to the gaining of results' (Mills 1985:170). Secularisation weakened the minister's external bases of authority and at the same time challenged his or her autonomy and inner sources of authority (Miner 2007:10). Individual rights and personal sovereignty have overthrown the moral authority that previously resided in state and church.

Clergy function as specialists and generalists. They are specialists in performing specific functions within a specific type of organisation (the church) and they are generalists in meeting members' needs as they arise. This may be termed 'duality of vocation' (see Fichter 1954:137).

The pace of life has increased tremendously (McDonagh 1975:659, 660). This has affected clergy's roles and responsibilities, including their time allocation and time management. Traditional ministerial responsibilities such as preaching, leading public worship (priestly role), pastoring, teaching, organising, and administrating remain, but their order of importance has changed and new activities have been added (Gustafson 1963:727-728). Other increased time pressures on clergy include decreased volunteerism within the church (Barna 1991:64-70, 242-244) and the fact that lay people are busier than ever as 'moderns live hectic lives' (London \& Wiseman 1993:39).

Leadership related pressures contribute to a clergy shortage. Frank (2006:118) observes that within the USA leadership is enmeshed with success. Church leadership has capitulated to success, in its contemporary business and economic definitions, and has forgotten to think historically or generationally (Frank 2006:118). Clergy want to be successful and can be competitive (Fryling 2010:29). The laity are influenced by a consumer culture built on discontentment; automatic loyalty to company or church no longer exists (Fryling 2010:30).

Hoge and Wenger (2005:50) indicate that some clergy leave the church for specialised ministry (another type of ministry). The majority of these become chaplains in various settings such as hospitals, retirement homes or the military, whilst a smaller percentage become campus ministers or denominational officers. According to their study, these clergy are the happiest and most satisfied as well as the largest category of ex-clergy (Hoge \& Wenger 2005:51, 64). Many clergy strongly indicated that they did not leave the church but merely changed their ministry to a different one (Hoge \& Wenger 2005:62-63).

With regards to family issues clergy couples experience the same strains as other dual career couples do: identity issues, work and role overload, role recycling problems, social network dilemmas and discrepancies between social and personal norms (Fogarty, Rapoport \& Rapoport 1971:23, 543, 547; cf. Kieren \& Munro 1988:240). One additional issue they face is the problem of handling the ambivalent boundary between work and family roles (Kieren \& Munro 1988:239). Frequently this leads to a 'two person, single career' situation where the spouse is often contributing resources without remuneration (Papanek 1973:853, 855, 858-860, 863). Two other factors affecting the clergy family are loneliness (Zoba 
1997:22; cf. Davis \& Milacci 2009:4, 14; Davis 2007:34, 109) and relocation (Littleton 1999:69-71; Hileman 2008:122-123).

Congregational conflict arises from many sources: job description expectations and discrepancies, inadequate training at seminary, and various other factors. Lummis (2003:4) indicates that there is a challenge facing both churches and clergy when determining the job description of pastors. Van Schalkwyk (2001:1; cf. Carroll 2002:10) points out that training at seminary is mostly focused on preparing clergy to be the 'only' pastor, probably the state of most congregations, and little is taught regarding building a team and functioning as one, and even less with regard to being a staff member.

Denominational conflict is another reason why clergy leave the church. It is often focused on 'clergy sexual misconduct, homosexuality, the ordination of women, and doctrinal issues' (Carroll, McMillan \& James 2002:3). Other areas regarding denominational conflict include lack of collegiality, lack of clear communication, personality clashes, authoritarian structures, and lack of support for the clergy. Another challenge for clergy is the search for balance between the institutional patterns and purposes of the church as an organisation and the personal needs and performance of the individual (Fichter 1970:82).

Stress and burnout increasingly affect today's society as more individuals than before are confronted with the emotional demands that are tied in with daily working for other people (Tomic, Tomic \& Evers 2004:227; cf. Hart 1984:113). Burnout is 'a psychological condition that results from chronic stress related to working with people' (Miner 2007:9; Maslach, Schaufeli \& Leiter 2001:397, 402-403). The central quality and most obvious manifestation of burnout is exhaustion (Maslach et al. 2001:402). Burnout consists of three components: emotional exhaustion, depersonalisation, and lack of personal accomplishment (Francis, Louden \& Rutledge 2004b:6; Maslach \& Jackson 1981:1). Findings of the study by Francis et al. (2004a:274) indicate that clergy who scored high on the index of emotional exhaustion were more likely to experience disagreement with their congregation, found it difficult to find people to fill roles in congregational life, doubted if they were the right kind of person for the congregation, felt their marriage and family life were negatively affected by the ministry, found it hard to deal with difficult and critical church service attenders or members, found it hard to make and keep close friends, felt high stress in their vocation, and often thought of leaving the ministry.

Clergy leave full-time pastoral ministry due to sexual misconduct. Some pastors and priests engage in extramarital affairs and sexually inappropriate behaviour (Moseley 2003:169; cf. Hoge \& Wenger 2005:24). The majority of sexual misconduct involves heterosexual extramarital affairs whilst sexual abuse of children is less common but not less concerning (Hoge \& Wenger 2005:24). The issue of practising homosexuality being classified as sexual misconduct is still a divisive issue amongst various denominations (Hoge \& Wenger 2005:24-25). Factors contributing to sexual misconduct amongst clergy include the 'star factor' from which the church is not exempt (Rediger 1990:15) as well as marital dissatisfaction (Thoburn \& Whitman 2004:502).

Divorce contributes to the clergy shortage. According to Zikmund, Lummis \& Chang (1998:40-43), the divorce rate of Protestant clergy and lay persons in America are the same. The same seems to hold true for Catholics (Roof \& McKinney 1987:156-157). In the past divorced clergy were the exception and divorce would most certainly end their careers, whilst at present divorce amongst clergy has a negative effect on their church career (Lummis 2006:169, 173). Factors that contribute to clergy divorce include the spouse working outside of the church, and ministry being a 24/7 'time-consuming and demanding occupation' (Lummis 2006:170-171). Being underpaid also contributes to divorce amongst clergy (Malebe 2004:162).

In the USA, very few pastors are paid at a professional salary level (McMillan \& Price 2003:7). Male clergy in the USA consider themselves as members of the professional middle class but this is fast changing in a downward direction (Price 2001:18-21). Clergy face economic challenges, such as taxation of monetary gifts (Frazier 2010:11-12), salaries that are dependent on church size (McMillan \& Price 2001:3; Miles \& Proeschold-Bell 2012:26), perceptions of clergy work as 'loafing', hence not worth a decent salary (Hotchkiss 2009), natural disasters such as hurricanes resulting in a reduced or no salary (The Christian Century 2005) and debt (Goetz 1997).

Factors contributing to clergy remaining in full-time salaried ministry include (when there is) a good fit between clergy and congregation, meaningful work, cooperation, commitment, mutual accountability, feedback, appropriate leisure time, and open negotiations regarding salary (Stephens 2003:1-4; Hoge \& Wenger 2005:35-45).

\section{Methodology}

A grounded theory methodology was used. Its origin can be traced back to sociology and it is widely used across many disciplines and subject areas (see Bryant \& Charmaz 2007:1). It comprises a systematically comparative inductive approach to gather data and build theory (Bryant \& Charmaz 2007:1; cf. Allan 2003:1-10; Charmaz 2006:2). Data are collected, coded, and compared in cyclical patterns until categories and their properties are identified. This continues until theoretical saturation has been achieved. Thereafter a substantive grounded theory is constructed.

Grounded theory methodology is qualitative in nature and engages various epistemologies. At present there are three main schools of grounded theory thought: Glaser, Strauss \& Corbin, and Charmaz. These three represent the current seven versions, namely positivist, post-positivist, constructivist 
(Charmaz), objectivist, postmodern, situational (Clarke), and computer assisted (Bryant \& Charmaz 2007:10). There are also three types: systematic design, emerging design, and constructivist design (Creswell 2005:397-402). Emerging design, as used in this study, is 'letting the theory emerge from the data rather than using specific, preset categories' (Creswell 2005:401).

Essentially this study followed a social or critical realism research paradigm, a depth realist ontology (reality consists in three domains: empirical, actual, and real), a neo-realist epistemology, a grounded theory methodology, using interviews as a method, and an abductive reasoning strategy.

Grounded theory methodology is well suited for a study on clergy shortage because in qualitative research, the researcher becomes the instrument. The researcher is 'the instrument that engages the situation and makes sense of it.' Moreover, 'it is the researcher's ability to see and interpret significant aspects ... that provide unique, personal insight into the experience under study' (Eisner 1991:33). Mills (1985:176) suggests that 'qualitative field studies are sorely needed to provide current and accurate descriptions of the world and work of the clergy.' He maintains that qualitative field studies are, 'when well done, the best way to discover the meaning of ministry from within' (Mills 1985:176).

\section{Swinton and Mowat (2006) point out that:}

practical theology is critical, theological reflection on the practices of the Church as they interact with the practices of the world, with a view to ensuring and enabling faithful participation in God's redemptive practices in, to and for the world' (p. 6; cf. Browning 2003:129)

It makes use of:

scientific models, concepts and methods developed to study religion in order to participate in academic research in general, though it has its own interest in relation to and difference from social sciences. (Heimbrock 2011:154)

Osmer (2008:4) lists the core tasks of practical theological interpretation as: the descriptive-empirical task, the interpretive task, the normative task, and the pragmatic task. In more layman terms, these tasks are addressed by the questions: what is going on, why is this going on, what ought to be going on, and how might we respond?

Combining the two approaches of grounded theory methodology from the social sciences and Osmer's practical theological interpretation (reflection from practical theology) meant that data could be interpreted within specific frameworks that intersect within everyday living, namely sociology and theology.

Participants were selected from the Hatfield Training Centre in Pretoria, South Africa. The criteria of having obtained an undergraduate degree, having been employed by a church (congregation or denomination), and having left fulltime pastoral ministry were used to select participants for interviewing. Respondents were all male as the only female reached declined to participate. All respondents received training at a Bible college of a charismatic mega church and the majority exited full-time pastoral ministry between their late twenties and mid-thirties. Each respondent had been in a full-time pastoral capacity, such as pastor, student pastor, congregational pastor, district pastor, associate pastor, assistant pastor.

Data were collected via one-to-one interviews. Participants were made to feel comfortable in an environment conducive to relaxed sharing. Informed consent forms were issued prior to the interviews to ensure ethical criteria were met. These were handed over before the interview and discussed before being signed. Consent was recorded via a digital recorder in the event of a telephonic interview. A request was made that they be available for a second interview in the event of the need to clarify content. Participants were offered the option to exit the process at any given time with no due penalty or repercussion. No incentives to participate were given except for the fact that the participants will be contributing to research and possible future interventions in clergy retention.

After the first round of three interviews, recordings were transcribed and coded (line by line and paragraph by paragraph). Initial codes (in vivo or theoretical) were assigned to the data. Thereafter further interviews were conducted, transcribed, and coded in batches. A cyclical pattern of interviewing, coding, and comparing followed until theoretical saturation was reached. Data analysis was conducted by comparing codes, categories, and concepts of the first interview to the second interview in order to identify similar or identical concepts and categories, along with their properties. This process was repeated with each additional interview. A total of 13 interviews were conducted with 10 men. Data obtained comprised of 4010 rows that were coded, resulting in more than 235 unique incidents. These were sorted into categories and their properties with casual relationships identified.

Both micro-analysis and open coding were applied as part of the initial coding to fragment the data and then conceptualise the data to describe what factors contribute to clergy leaving full-time pastoral ministry (Van Zyl 2010:154). Using extracts from the interviews enabled me to present the clergy's first hand experiences and perspectives.

\section{Findings}

Clergy do not feel appreciated (Stephens 2003:1-4; Hoge \& Wenger 2005:35-45) or affirmed (Baars 2003:1) which are two of the main reasons why they leave the church. Lack of encouragement contributes to this (Coles 2002:22-28). One respondent stated:

'I didn't feel appreciated to be honest and I didn't feel, I didn't feel appreciated, um that what I was doing for the church ... It came to the point where I felt, I eventually felt unappreciated.' (Participant 4)

Clergy also feel they are not being heard. A respondent related it this way: 
'Disappeared and no one asked a question, no one enquired. That, that baffled me. How can a church have a leader, a shepherd just disappear and not ask 'but where are you? What happened?' And that happened and I saw that happen with a lot of the people in the congregation. That just, they just a number.' (Participant 1)

Where there is an opportunity to provide or receive feedback they remain and do not leave the church (Stephens 2003:1-4).

Clergy respond to a call in different ways. Some contemporary clergy consider a call to be 'seasonal' or 'dual' (for example, pastoral and business in tandem) whilst past clergy considered a call to be a lifetime commitment with stringent conditions of morality accompanying it (Chapin 1842:264). A respondent said:

'I was very clear of my calling. I was called to, to, to well what I understood at that point of time was as a missionary. Um but I also knew when I was completing my um, education, my that I was going to go for a season into pastoral work and from there uh into missions - I think it was more a matter of grasping the realities of what does it mean to be a pastor not just from a biblical point of view but from a practical point of view so but even before we accepted a calling into a local church I knew that this would be a season.' (Participant 13)

The literature review identified that clergy leave when they receive a new calling (a different ministry or vocation) and consider it time to leave when the work has been completed (Stephens 2003:1-4; Hoge \& Wenger 2005:35-45). Kendall (a retired minister of Westminster Chapel [after 25 years of service from 1977 to 2002] pers. comm., 2011) is of the view that some clergy who leave the church were not 'called to the ministry' in the first place.

Clergy leave the church when challenging their leaders produces negative or no results. One respondent stated it this way:

'If I don't agree with something, if I see something differently, I will challenge it. And what I have seen is and this in $99 \%$ of the time with church leaders specifically what I saw was when, me, I am not saying it is that way with everybody else but when I used to challenge a leader - just get cut off ... And then at some point you don't challenge anymore ... Well, I ended up leaving.' (Participant 1)

Clergy have not escaped the battle against authority; they too challenge leaders (Fisher 1996:230-231). With respect to individualism, traditional church authority structures have been questioned in the name of personal preferences and professional autonomy (Mills 1985:171). Clergy have been influenced by an increased emphasis on 'values of self-determination, personal gratification, individual rights, and interpersonal communication in society at large' (Mills 1985:171). Professionalism has influenced clergy by steering the 'focus of the clergy's work from fulfilling a traditional calling to the gaining of results' (Mills 1985:170).

Clergy leave the church due to conflict. These include frustration with ecclesiastical structures and Episcopal policies, size and concentration of the diocese, and conflict with leadership (Seidler 1979:763, 765; cf. Coles 2002:22-28). One respondent said:

'[O]ver a period of time um, a lot of times um, the senior pastor and myself we bumped um, we clashed a lot and nobody really had the boldness to stand up to him. I was maybe one of the people that did and uh, you know so we clashed, we clashed, at times.' (Participant 11)

Training in managing conflict is inadequate at seminary level (Van Schalkwyk 2001:1; cf. Carroll 2002:10). Hart (1984:115) indicates that ministers are not adequately trained to handle conflict situations, difficult personalities, or communication problems. Most conflict is in the area of leadership style (Hoge \& Wenger 2003:7) as indicated by this respondent's statement:

'And then the senior pastor said to the youth pastor, "This is my congregation, this is my church and I will make [do] as I want to." And that is where I decided, this is my point where I say good bye ... Well, when I heard him say that to the youth pastor, that's control, that is manipulation, I am not going to stand for that, I am not going to be under that.' (Participant 1)

Clergy desire some form of control in their own lives and vocation. One respondent (participant 2) stated, 'I think it felt better because I felt I knew I was in charge ... Ja. [Translation: Yes] I could make decisions.' Clergy tend to stay when there is a good fit, meaningful work, cooperation, commitment, mutual accountability, feedback, appropriate leisure time, and open negotiations regarding salary (Stephens 2003:1-4; Hoge \& Wenger 2005:35-45).

Finances influence the retention of clergy in the church. Clergy seek open negotiations regarding salary (Stephens 2003:1-4; Hoge \& Wenger 2005:35-45). They are not considered professional (Brauer-Rieke 2012:1) and are not paid professionally (McMillan \& Price 2003:7), yet see themselves as professional, according to Fichter and Glasse (in Gannon 1971:69; cf. Hoge 2009:581). Compensation influences clergy in their decision to accept a call to a church (Wildhagen, Mueller \& Wang 2005:396). This study did not find any clergy leaving the church due to a lack of finances. However, one of the respondents indicated his shame in having to depend on his wife's family to provide finances for his children's needs (participant 11) whilst others indicated that they struggled with insufficient income (particpant 1, 4, and 7). One respondent explained it as:

'The responsibilities as student pastor for me that side, was everything that the pastor did, just for a tenth of the pay [laugh]. ... Um, ja [Translation: Yes], money was, whew, money is always a big issue. Um, especially in the church. I think times have changed a little bit, um, back then it almost seemed like you work for the church. And you do five peoples work and you get paid half of a person's pay. It is like ... [chuckle].' (Participant 1)

Clergy leave due to being mismatched and stay when there is a good fit (Stephens 2003:1-4; Hoge \& Wenger 2005:35-45). Participant 2 stated it this way:

'I knew I wasn't, that's not what God had for me and that's not what was in my heart and that was not what I wanted to do, I could, I could um, I could do it. I could put my heart behind it and change things and make it work but I knew that at the end of the day I was, I was, feel this is not it.' 
Personality clashes also contribute to clergy leaving (McDonagh 1975:658). Clergy deal with the church as an institution. During their response to a call they undergo a change regarding this institution from being idealistic to being realistic, gaining an appreciation for the interpersonal or political aspects of the priesthood, realising the difficulty in bringing about change, and are confronted by the underutilisation of their skills by their overseeing pastor (Hall \& Schneider 1973:116-117). The aspect of church as an institution or organisation that is perceived by respondents as a 'game with rules' (participant 2) and as a system that 'hammers people' (participant 1 and 7) also surfaced. There was an awareness of church politics that was experienced negatively (participant 11). Participant 7 stated it this way:

'It's not very dissimilar to the church's environment in the sense that if something goes wrong we tend to hammer people, here today, leave tomorrow ... I must say I did not leave the student pastorship program without any baggage - certainly my attitude towards the church in terms of politics and in terms of human nature [became my baggage].'

Job description related issues contribute to clergy leaving the church. On the one hand there is an underutilisation of clergy skills by their leaders (Hall \& Schneider 1973:116-117). On the other hand the job is never finished (Sandford 1982:515) which results in a 'stressful calling that is conducive to burnout' (Miner 2007:9). Work overload with no clear boundaries contributes to the incidence of burnout amongst clergy (Hart 1984:113-114). Participant 2 used these words to indicate this: 'The job is like, open ended.' Search committees appointed to place clergy often have insufficient knowledge of what is really involved in pastoral leadership or of the church's mission (Lummis 2003:4). Clergy job descriptions are determined by many outside sources, for example, church members, official documents, colleagues, theological educators, secular literature, ecclesiastical superiors, role models, the Scriptures, talk-show hosts, amateurs, troubled people, family, community, church organisational structures, and then the pastor him- or herself (London \& Wiseman 1993:57-61). Findings in this study indicated that there is a contrast between clergy not being told what is expected of them (unclear job descriptions) as opposed to the literature review that indicates too many sources are telling them what to do (London \& Wiseman 1993:57). Yet, what clergy are to do and how, remains undefined in contrast to other professions (Niebuhr, Williams \& Gustafson 1956). Although none of the respondents indicated they left the church due to job description related issues, one respondent indicated that he experienced scope creep with more responsibilities being added to his job description (participant 2) whilst others indicated that their job descriptions were unwritten, unclear, or open-ended (participant 1,2, and 11).

Church leadership influences clergy. Favouritism affects clergy negatively as indicated by one respondent (participant 3): 'You know XXX always had his blue eyed boys; there was always someone on the staff whom he favoured more than others.' Autocratic or laissez-faire leadership styles affect curates (an assistant to a vicar, rector, or parish priest) negatively (Hall \& Schneider 1973:70-71). One respondent said:
'[I] struggled through that, I struggled with seeing church leadership that way, you know it sounds like Zimbabwe, sounds like it, sounds like, is that supposed to be in the church now? This control thing and this fear for the father. I cannot question, I cannot, is that what's supposed to be the church, and I ja [Translation: Yes], as far as I'm concerned, I don't see it.' (Participant 2)

Fernandez (2001:27) observed that the manner in which a bishop deals with a priest under his care influences the decision to leave or not. Pastors who share important duties and responsibilities with their curates, encouraging them to take initiative and innovate, provide a rewarding work experience (cf. Hoge \& Wenger 2003:6-7).

Clergy deal with crisis in various ways. Mills (1985:173) lists exit, voice, and stress as three possible expressions of dealing with underlying crises. Exit is the actual departure from a troubled organisation and voice is an attempt to change the organisation (Mills 1985:172; Hirschman 1970:21-30). Stress may lead to either exit or active voice (Mills 1985:172). Clergy deal with change in ministry using exit, voice, or stress (Mills 1985:172). The findings of this study indicate that clergy deal with crisis by leaving for different reasons. One respondent chose to hide his reason for leaving due to his mistrust of leadership (participant 2). Another respondent left due to the high levels of stress he was experiencing - some stress was self-induced and some was from others (particpant 11). Still another left due to 'manipulation and control' by the leadership (participant 1) as well as not being heard (participant 1). One respondent indicated that nepotism was a strong contributing factor to leaving full-time pastoral ministry (participant 2). Being overworked was also a reason for leaving (participant 4) as was not being appreciated (participant 4). Personality clashes and strained relationships resulted in some respondents leaving (participant 2 and 4). One respondent stated that a wrong fit led to his exit from full-time pastoral ministry (participant 7). Frustration was another contributing reason for leaving (participant 4 and 12). Finances were yet another (participant 4). One respondent said that God told him to leave and others had confirmed it (participant 11).

\section{Discussion}

Clergy respond to a call. Other professions may term this a response to a vocation. For clergy a call involves, amongst other things, a spiritual aspect which is demonstrated in service to God and the faith community within the structure or organisation of the church. Responding to this call requires spiritual formation, theological preparation, and dealing with experiences that either validate or challenge the call. The following are the findings from the participants:

- Not all clergy have a deep sense of calling to full-time pastoral ministry yet often function within this position.

- The rationale for clergy doing so is that it is 'only for a season' or 'a stepping stone' to something else (either business or missions). 
- Preparation for full-time pastoral ministry is usually within a formal setting such as a Bible college or seminary.

- This preparation is considered, by ex-clergy, to be insufficient for the scenarios they were to face in full-time pastoral ministry.

- The call is an evolving process whereby the call is identified, sometimes adjusted, the cost considered, and sometimes a change in direction chosen (to either business or missions).

- Prior 'worldly experience' is regarded as conducive to understanding congregants' situations.

- Proper timing in being released into full-time pastoral ministry is seen in a positive light whilst a premature release has been observed by ex-clergy to have an adverse effect.

- Encouragement by leaders was instrumental in the path taken to prepare and grow in the call.

- 'Being heard' is an important positive ministry experience incident that reinforces the call.

- 'Being affirmed' is an important positive ministry experience incident that reinforces the call.

- 'Being forgotten' is an important negative ministry experience incident that weakens the call.

- The issue of control often led to challenging leadership concerning a situation, behaviour, or policy.

- Challenging leaders or leadership occurred when respondents felt they had no control over their own lives or control in fulfilling their calling or even influencing a particular situation.

- Freedom to act or to influence is considered a positive ministry experience incident - however, the definition of what constitutes freedom is vague.

- The church is viewed as an institution or organisation that is a 'game with rules' which 'hammers people' when they break the rules.

- Conflict intensity and frequency is linked to age younger pastors are more likely to allow their youthful zeal to contribute to a poor handling of conflict situations.

- Conflict situations occur where nepotism, favouritism, personality clashes, and a lack of control over one's own destiny are present.

- Incompatible fit in terms of mentorship, an overseeing pastor, or job function contributes to frustration whilst a compatible fit 'energises'.

- The cost of ministry can be high, particularly for clergy marriages and families.

- Job descriptions are often unclear, open-ended with scope-creep of more responsibilities, and unwritten.

- Lack of finances and unclear job descriptions add pressure to clergy but are not reasons for their exodus.

- Reasons for leaving included mistrust of leadership, high levels of stress, 'manipulation and control' by leadership, not being heard, nepotism, being over-worked, not being appreciated, personality clashes, a wrong 'fit', frustration, finances, and God's instruction.

Not all clergy are necessarily called to full-time pastoral ministry; hence there should be a differentiation between what type of training is offered and to whom. The Cambridge
Theological Federation website views Practical Theology as a discipline in which anyone and everyone can participate even if not called to pastoral ministry. Full-time pastoral ministry as a vocation requires knowing that one is called to it. This call is what provides endurance or perseverance through tough times (consider the prophet Jeremiah's call). Knowing the call and living it is not a guarantee that none will leave the ministry or later deny their call. Preparation for responding to the call often lacks real-world scenario training which for clergy is conducive to understanding congregants' situations. Preparation for responding to the call should include the correct timing in being released into ministry, as a premature release seems to have an adverse effect on clergy remaining in full-time pastoral ministry.

The influence of leaders is a crucial factor with a lack of encouragement, not being heard, not being affirmed, and being forgotten by leaders, all contributing to clergy leaving full-time pastoral ministry. Even more critical is the issue of control by leadership which results in clergy challenging church leaders when they feel they have no control over their own lives, control in fulfilling their calling, or even influencing a particular situation. An incompatible fit in terms of mentorship, an overseeing pastor, or job function, plays a role in clergy leaving full-time pastoral ministry. More attention should be given to this area as it has the potential for the greatest damage or success with regards to the future of the church. This researcher has come across situations where much was expected of the trainee pastor yet not much was invested by the overseeing pastor. The overseeing pastor had not been coached in how to mentor.

Clergy have experienced the church as an institution or organisation that is a 'game with rules' which 'hammers people' when they break the rules. If this is how the church is viewed by those who have a positive affinity for it, what will be the view of those who are not part of it? Job descriptions would be one area where this 'hammer' is felt. With job descriptions being unclear, open-ended, and unwritten there is a need for assessing the current status quo and a 'business process re-engineering' in order to protect both the professional and the organisation. The cost of ministry to marriage and family should be addressed in clergy training with possible boundaries being considered. Although finances are not a major reason for leaving, the lack thereof did contribute stress to clergy. It would seem that as a called pastor one is more than adequately rewarded but as a professional it often falls short compared to other professions.

Currently, training of pastors within my context is through a Bible college at a mega church. However, the likelihood of a graduate entering ministry in a mega church is slim, whilst the challenges of lack of resources and loneliness contribute to an aversion of placement in a rural setting. A solution could be that a mega church part-sponsors a rural church pastor and enables him or her to mostly focus on ministry and not finances. The revision of curriculum is already under 
way at this researcher's training institution with a greater focus on the practical aspects of ministry. Consideration is being given to the training of baby boomers, those who are entering a second career, as well as the usual younger high school graduates.

Finally, in South Africa it is necessary to understand our African context. Currently Western thought mostly directs clergy training. How, for instance, is a pastor to address a situation of a person 'possessed by a water spirit'? An academic, theological foundation alone would not suffice. This is merely a beginning. Practical training within our African context needs to equip called clergy in addressing the needs of their local congregations. Since practical theology is 'the theologically positioned, interdisciplinary study of the practices of religious communities and of the traditions and social contexts that shape and challenge those practices', it is necessary to address our context (Boston University handbook 2011; Swinton \& Mowat 2006:6; Browning 2003:129). This training should include both the spiritual formation aspect as well as practical tools such as preventing and dealing with burnout. All of the points listed above provide opportunities for future research.

Recommendations for future studies include the following: a quantitative survey of clergy exodus, turnover, and retention in South Africa; ascertaining the viability of establishing a clergy renewal program within South Africa; the viability of promoting partnerships between urban and rural churches for the placement of clergy; revising of curriculum at theological institutions; and, what the call to full-time pastoral ministry looks like within a feminist theology or liberation theology context within South Africa.

An extensive quantitative survey involving numerous denominations would assist in mapping the magnitude of clergy turnover and retention within the South African context. This could be funded by a partnership between the National Research Foundation, university grants, and the private sector. A clergy renewal program such as that which the Lilly Endowment presents in the USA could assist in increasing the effectiveness of clergy ministry as well as the retention of called clergy by empowering them to deal with the demands of ministry. Partnerships between urban and rural churches, especially in training of clergy would assist with the challenge of clergy placement in Protestant churches.

The question is whether there is an exodus of clergy. Within the Roman Catholic Church the answer is 'yes' whilst in the Protestant churches the answer is 'no' as these face more of a placement challenge than a shortage. Within my context of a Protestant charismatic mega church there is no shortage. The challenge is one of placement and adequate preparation for, and in particular, a rural or small church placement. Another question is whether clergy leave full-time pastoral ministry in the church as an organisation. Yes, they do. According to this study they leave because they were not necessarily called to full-time pastoral ministry within the church in the first place and because church leadership responses have not always been favourable towards clergy that are preparing and responding to their call. Within my context of a Protestant charismatic mega church the requirement for assessing the call of each candidate as well as their specific equipping in line with that call, will need focused attention. It will require leaders who mentor aspiring clergy to correctly assess, appropriately affirm, and purposely develop the call of these clergy in conjunction with their dreams, ideals, and will. There is a need for retraining the trainers (leaders) in order to better equip them at preparing the next generation of clergy for the task at hand, namely, the discipleship of the faith community.

\section{Acknowledgements Competing interests}

The authors declare that they have no financial or personal relationship(s) which may have inappropriately influenced them in writing this article.

\section{Authors' contributions}

This article represents a reworked version of aspects from the PhD dissertation of S.J. (University of Pretoria), with Y.D. (University of Pretoria) as supervisor.

\section{References}

Allan, G., 2003, 'A critique of using grounded theory as a research method', Electronic Journal of Business Research Methods 2(1), 1-10.

Baars, C.W., 2003, 'The role of the church in the causation, treatment, and prevention of the crisis in the priesthood', in Internations' Justice Federation Halifax, viewed 15 May 2010, from http://www.restoringdignity.org/priesthoodcrisis.html

Barna, G., 1991, What Americans believe, Regal Books, Ventura, CA.

Boston University's Handbook 2011, 'School of Theology, Doctor of Philosophy (Ph.D.)' in Practical Theology degree handbook, viewed 16 April 2011, from http://www.bu.edu/sth/files/2011/03/DoctorofPhilosophyHandbookRevised March2011withThesisGuide.pdf

Brauer-Rieke, D., 2012, 'Compensation and benefits guidelines for clergy', pp. 1-29, in Soul Cafe, viewed 21 October 2012, from http://soulcafe.org/sites/default/ files/2013_clergy_guidelines_approved.pdf

Browning, D.S., 2003, Marriage and modernization: How globalization threatens marriage and what to do about it, Eerdmans, Grand Rapids, MI.

Bryant, A. \& Charmaz, K., 2007, 'Grounded theory research: Methods and practices', in A. Bryant \& K. Charmaz (eds.), The sage handbook of grounded theory, pp. 1-29, Sage, London. PMid:17472223

Cahill, L.S., 2012, 'James M. Gustafson and Catholic theological ethics', Journal of Moral Theology 1(1), 92-115.

Carroll, J.W., 2001, "Reflections of a clergy-watcher", retirement lecture, Duke University Divinity School, 18 April', in Pulpit \& pew: Research on pastoral leadership, viewed 30 October 2008, from http://pulpitandpew.org/sites/all/ themes/pulpitandpew/files/clergywatcherlecture.pdf

Carroll, J.W., 2002, “"The more things change . . .": Pastoral leadership for the 21st century', in The Claremont School of Theology, 'The Ernest Cadman Colwell Lecture, 12 September 2002', viewed 30 October 2008, from http://hirr.hartsem.edu/ leadership/clergyresources.html and http://pulpitandpew.org/other-publications

Carroll, J.W., 2006, God's potters: Pastoral leadership and the shaping of congregations, Eerdmans, Grand Rapids, MI.

Carroll, J.W., McMillan, B.R. \& James, J.B., 2002, 'Selected findings from the national clergy survey', in Pulpit \& pew: Research on pastoral leadership, viewed 30 October 2008, from http://pulpitandpew.org/sites/all/themes/pulpitandpew/ files/clergy_letter_1.pdf

Chapin, A.B., 1842, A view of the organization and the order of the primitive church: Containing a scriptural plan of the apostolic church; with a historical outline of the church to the end of the second century, Hitchcock \& Stafford, New Haven, viewed 05 May 2010, from http://books.google.co.za/books?id=rlEHARRjiw QC\&printsec=frontcover\&dq=is+the+church+an+organization\%3F\&ei=LnzhS jWCJuywTU17WiDA\&cd=10\#v=onepage \&q\&\%20f=false

Charmaz, K., 2006, Constructing grounded theory: A practical guide through qualitative analysis, Sage, London.

Chaves, M., 2001, 'Challenges for the 21st century', The Journal of the Interim Ministry Network, 2001 Annual Review, December, 27-39. 
Coles, N., 2002, 'Ministry fallout: Can we afford it? Can we prevent it?', Ministry Today $24,22-28$.

Creswell, J.W., 2005, Educational research: Planning, conducting, and evaluating quantitative and qualitative research, 2nd edn., Pearson, Upper Saddle River, NJ.

Davis, J.L., 2007, 'Alone in a crowd: A phenomenological inquiry into loneliness as experienced by pastors' wives', PhD thesis, Liberty University.

Davis, J.L. \& Milacci, F., 2009, 'Quantum of solitude: Loneliness as experienced by pastors' wives', Faculty Publications and Presentations, Paper 52, viewed 03 November 2010, from http://digitalcommons.liberty.edu/ccfs_fac_pubs/52

Eisner, E.W., 1998, The enlightened eye: Qualitative inquiry and the enhancement of educational practice, Merrill, Upper Saddle River, NJ.

Fernandez, E.R., 2001, Leaving the priesthood: A close reading of priestly departures, University of Ateneo, De Manila Press, Manila, Philippines.

Fichter, J., 1954, Social relations in the urban parish, University of Chicago Press, Chicago. PMid:13206390

Fichter, J., 1970, 'Catholic church professionals', Annals of the American Academy of Political and Social Science 387(January), 77-85. http://dx.doi. org/10.1177/000271627038700110

Fisher, D., 1996, The 21st century pastor: A vision based on the ministry of Paul, Zondervan, Grand Rapids, MI.

Fogarty, M.P., Rapoport, R. \& Rapoport, R.N., 1971, Sex, career, and family, PEP, Allen \& Unwin, London.

Francis, L.J., Kaldor, P., Shevlin, M. \& Lewis, C.A., 2004a, 'Assessing emotionalexhaustion among the Australian clergy: Internal reliability and construct validity of the scale of emotional exhaustion in ministry (SEEM)', Review of Religious Research 45(3), 269-277. http://dx.doi.org/10.2307/3512264

Francis, L.J., Louden, S.H. \& Rutledge C.J.F., 2004b, 'Burnout among Roman Catholic parochial clergy in England and Wales: Myth or reality?', Review of Religious Research 46(1), 5-19. http://dx.doi.org/10.2307/3512249

Frank, T.E., 2006, 'Leadership and administration: An emerging field in practical theology (a research report)', International Journal of Practical Theology 10(1), theology (a research report)', International Journal

Frazier, E., 2010, 'Mixed blessings: Love offerings prove taxing', Christianity Today, viewed 21 October 2012, from http://www.christianitytoday.com/ct/2010/ july/3.11.htm

Fryling, R.A., 2010, The leadership ellipse: Shaping how we lead by who we are, Intervarsity, Downers Grove. IL.

Gannon, T.M., 1971, 'Priest/minister: Profession or non-profession?', Review of Religious Research 12(2), 66-79. http://dx.doi.org/10.2307/3510079

Glasse, J.D., 1968, Profession: Minister, Abingdon, Nashville, TN.

Goetz, D.L., 1997, 'Is the pastor's family safe at home?', Leadership Journal 13(Spring), viewed 27 October 2012, from http://www.christianitytoday.com/le/1997/ spring/7|2084.html?start=2

Gustafson, J.M., 1963, 'The clergy in the United States', Daedalus 92(4), 724-744.

Gustafson, J.M., 1965, 'Context vs. principles: A misplaced debate in Christian ethics', The Harvard Theological Review 58(2), 171-202. http://dx.doi.org/10.1017/ S0017816000031308

Hall, D.T. \& Schneider, B., 1973, Organizational climates and careers: The work lives of priests, Seminar Press, New York, NY.

Hart, A.D., 1984, Coping with depression in the ministry and other helping professions, Word Books, Waco, TX.

Heimbrock, H., 2011, 'Practical theology as empirical theology', International Journal of Practical Theology 14(2), 153-170. http://dx.doi.org/10.1515/IJPT.2011.013

Hileman, L., 2008, 'The unique needs of Protestant clergy families: Implications for marriage and family counselling', Journal of Spirituality in Mental Health 10(2), 119-144. http://dx.doi.org/10.1080/19349630802081152

Hirschman, A.O., 1970, Exit, voice, and loyalty: Responses to decline in firms, organizations, and states, Harvard University Press, Cambridge, MA.

Hoge, D.R., 2009, 'The sociology of clergy', in P.B. Clarke (ed.), The Oxford handbook of the sociology of religion, n.p., Oxford University Press, New York.

Hoge, D.R. \& Wenger, J.E., 2003, 'Experiences of protestant ministers who left local church ministry', paper presented to the Religious Research Association, Norfolk VA, October 25, 2003, in Pulpit \& Pew: Research on pastoral leadership, viewed 19 May 2008, from http://pulpitandpew.org/sites/all/themes/pulpitandpew/ files/Hoge.pdf

Hoge, D.R. \& Wenger, J.E., 2005, Pastors in transition: why clergy leave local church ministry, Eerdmans, Grand Rapids, MI. PMCid:2692693

Hotchkiss, D., 2009, 'Why pay the preacher?', in Alban Publishing, viewed 21 October 2012, from http://www.alban.org/conversation.aspx?id=8796

Jud, G.J., Mills, E.W. Jr., \& Burch, G., 1970, Ex-pastors, Pilgrim, Boston.

Kieren, D.K. \& Munro, B., 1988, 'Handling greedy clergy roles: A dual clergy example', Pastoral Psychology 36(4), 239-248. http://dx.doi.org/10.1007/BF01760099

Littleton, J.G., 1999, 'The displaced parsonage', Your Church 45(6), 69, viewed 09 December 2012, from http://0-search.ebscohost.com.innop ac.up.ac.za/login.as px?direct $=$ true $\& d b=f 5 h \& A N=2516360 \&$ site $=$ ehost-live \&scope $=$ site

London, H.B. Jr \& Wiseman, N.B., 1993, Pastors at risk: Help for pastors, hope for the church, Victor Books, Wheaton, IL.

Lummis, A.T., 2003, 'What do lay people want in pastors?: Answers from lay search committee chairs and regional judicatory leaders', in Pulpit and Pew: Research on pastoral leadership, Research Reports, No. 3, Winter 2003, Durham North Carolina: Duke Divinity School, viewed 30 October 2008, from http:// pulpitandpew.org/what-do-lay-people-want-pastors-answers-lay-searchpulpitandpew.org/what-do-lay-people-want-pas
committee-chairs-and-regional-judicatory-leaders
Lummis, A.T., 2006, 'Divorce among protestant clergy', in P. Hegy \& J. Marots (eds.), Catholic divorce: The deception of annulments, n.p., Continuum, New York.

Malebe, G.N., 2004, 'The phenomenology of divorce among apostolic faith mission of South Africa's pastors: A practical theological perspective', PhD dissertation Faculty of Arts, Randse Afrikaanse Universiteit (know as the University of Johannesburg).

Maslach, C. \& Jackson, S.E., 1981, MBI: Maslach Burnout Inventory: manual research edition, 2nd edn., Consulting Psychologists Press, University of California, Palo Alto, CA.

Maslach, C., Schaufeli, W. \& Leiter, M., 2001, 'Job burnout', Annual Review of Psychology 52(1), 397-422. http://dx.doi.org/10.1146/annurev.psych.52.1.397, PMid:11148311

McDonagh, E., 1975, 'Why do they leave?', The Furrow 26(11), 652-667.

McMillan, B.R. \& Price, M.J., 2001, 'At cross purposes? Clergy salaries: Market and mission', in Pulpit \& pew: Research on pastoral leadership, viewed 21 October 2012, from http://pulpitandpew.org/sites/all/themes/pulpitandpew/files/ atcrosspurposes.pdf

McMillan, B.R. \& Price, M.J., 2003, 'How much should we pay the pastor? A fresh look at clergy salaries in the 21st century', in Pulpit \& pew: Research on pastora leadership, winter 2003, viewed 21 October 2012, from http://pulpitandpew.org/ sites/all/themes/pulpitandpew/files/salarystudy.pdf

Miles, A. \& Proeschold-Bell, R.J., 2012, 'Are rural clergy worse off?: An examination of occupational conditions and pastoral experiences in a sample of united Methodist clergy', Sociology of Religion 73(1), 23-45. http://dx.doi.org/10.1093/socrel/ srr025

Mills, E.W., 1985, 'The sacred in ministry studies', in P.E. Hammond (ed.), The sacred in a secular age, n.p., University of California Press, Los Angeles, CA.

Miner, M.H., 2007, 'Changes in burnout over the first 12 months in ministry: Links with

stress and orientation to ministry', Mental Health, Religion \& Culture 10(1), 9-16. http://dx.doi.org/10.1080/13674670600841819

Moseley, N.A., 2003, Thinking against the grain: Developing a biblical worldview in a culture of myths, Kregel, Grand Rapids, MI.

Niebuhr, H.R., Williams, D.D. \& Gustafson, J.M., 1956, 'The purpose of the church and its ministry', in Religion online, viewed 03 June 2010, from http://www.religiononline.org/showchapter.asp?title $=407 \& C=152$

Osmer, R.R., 2008, Practical theology: An introduction, Eerdmans, Grand Rapids, MI.

Papanek, H., 1973, 'Men, women, and work: Reflections on the two-person career', The American Journal of Sociology 78(4), 852-872. http://dx.doi.org/10.1086/225406

Percy, M., 2006, Clergy: The origin of species, Continuum, London.

Price, M.J., 2001, 'Male clergy in economic crisis: Fear of falling', Christian Century $118,18-21$.

Rediger, G.L., 1990, Ministry \& sexuality: Cases, counselling, care, Augsburg, Minneapolis, MN. PMid:1981878

Roof, W.C. \& McKinney, W.J., 1987, American mainline religion: It's changing shape and future, Rutgers University Press, New Brunswick, NJ.

Sandford, J.A., 1982, Ministry burnout, Westminster John Knox, Louisville, KY. PMCid:347607

Seidler, J., 1979, 'Priest resignations in a lazy monopoly', American Sociological Review 44(5), 763-783. http://dx.doi.org/10.2307/2094527

Stephens, J., 2003, 'A resource for congregations from Hamilton conference staff', Canada: Team Works, Hamilton Conference, The United Church of Canada, viewed 06 May 2010, from http://www.hamconf.org/TW_Ministers.pdf

Swinton, J. \& Mowat, H., 2006, Practical theology and qualitative research, SCM, London.

Tentler, L.W., 1998, "'God's representative in our midst": Toward a history of the Catholic diocesan clergy in the United States', Church History 67(2), 326-349. http://dx.doi.org/10.2307/3169764

'Storms wreck churches, clergy salaries', The Christian Century 122(23), viewed 20 October 2012, from http://0-go.galegroup.com.innopac.up.ac.za/ps/i.do?id $=$ GALE\%7CA138998101\&v=2.1\&u=up_itw\&it=r\&p=AONE\&sw=w

Thoburn, J. \& Whitman, D.M., 2004, 'Clergy affairs: Emotional investment, longevity of relationship and affair partners', Pastoral Psychology 52(6), 491-506. http:// dx.doi.org/10.1023/B:PASP.0000031528.62048.8b

Tomic, W., Tomic, D.M. \& Evers, W.J.G., 2004, 'A question of burnout among Reformed Church ministers in The Netherlands', Mental Health, Religion \& Culture 7(3), 225-247. http://dx.doi.org/10.1080/13674670310001602472

Trull, J.E. \& Carter, J.E., 2004, Ministerial ethics: Moral formation for church leaders, 2nd edn., Baker Academic, Grand Rapids, MI. PMCid:429387

Van Schalkwyk, G.E., 2001, 'n Ondersoek na die samestelling van 'n multi-leraarspan vir 'n gemeente', MA thesis, Randse Afrikaanse Universiteit (bekend as die Universiteit van Johannesburg).

Van Zyl, M., 2010, 'Coping strategies for leaders during an economic downturn', unpublished PhD thesis, University of Pretoria.

Wildhagen, T., Mueller, C.W. \& Wang, M., 2005, 'Factors leading to clergy job search in two Protestant denominations', Review of religious research 46(4), 380-403. http://dx.doi.org/10.2307/3512168

Zikmund, B.B., Lummis, A.T. \& Chang, P.M.Y., 1998, Clergy women: An uphill calling, Westminster John Knox, Louisville, KY.

Zoba, W.M., 1997, 'What pastors' wives wish their churches knew', Christianity Today, 07 April, pp. 20-26, viewed 09 December 2012, from http://www. christianitytoday.com/ct/1997/april7/7t420a.html 